\title{
Effect of Nitrogen and Two Types of Green Manure on the Changes in Percentage and Yield of Peppermint (Mentha piperita) Essential Oil
}

\author{
Reza Dehghani BIDGOLI ${ }^{1 *}$, Mohammad Javad MAHDAVI² \\ ${ }^{1}$ University of Kashan, Faculty of Watershed and Rangeland Management, Kashan, Iran; dehghanir@kashanu.ac.ir (*corresponding author) \\ 2Payame Noor University, Agricultural Sciences Department, 19395-4697 Tehran, Iran; mjmahdavi@gmail.com
}

\begin{abstract}
An experiment was conducted during 2015-2016 as a split factorial in a randomized complete block design (RCBD) with three replications. Experimental factors were nitrogen fertilizer at four levels 0, 50, 100 and $150 \mathrm{~kg} / \mathrm{ha}$ as the main factor and two types of green manure. Alfalfa (Medicago sativa) and secale (Secale montanum) in two states (use and non-use) were considered as sub-factors. Medicago sativa and Secale montanum were cultivated as green manure in September 2015 and returned into the soil by ploughing at the fall of 2015. Thereafter, Mentha piperita was planted and the crop was taken care of in order to collect the samples. The highest increase of peppermint essential oil percentage and essential oil yield in different treatments resulted from the application of $150 \mathrm{~kg} / \mathrm{ha}$ of pure nitrogen with $0.35 \%$ and $45.60 \mathrm{~kg} / \mathrm{ha}$, as well as the use of $M$. sativa with $0.43 \%$ and $55.80 \mathrm{~kg} / \mathrm{h}$, the use of $S$. montanum with $0.44 \%$ and $49.50 \mathrm{~kg} / \mathrm{ha}$, respectively. The highest essential oil percentage and essential oil yield were recorded under the influence of the double interaction use of $150 \mathrm{~kg} / \mathrm{ha}$ of pure nitrogen and use of green manure of $M$. sativa with average $0.62 \%$ and $80.30 \mathrm{~kg} / \mathrm{ha}$, respectively. The triple interaction of experimental factors on traits tested showed that nitrogen treatment of $150 \mathrm{~kg} / \mathrm{ha}$ with $M$. sativa and $S$. montanum produced the highest percentage of essential oil and essential oil yield of average $0.73 \%$ and $91.65 \mathrm{~kg} / \mathrm{ha}$, respectively.
\end{abstract}

Keywords: essential oil; fertilizer; medicinal plant; Medicago sativa; Secale montanum

\section{Introduction}

The research was carried out to investigate the effect of culture techniques and nutritional methods on essential oil yield of peppermint. Peppermint (Mentha piperita L.), which belongs to the family Lamiaceae is a hybrid species obtained from the confluence of Mentha spicata and Mentha aquatica species (Foster, 1996; Peirce, 1999). This plant species is a perennial plant, with a height of 50 to 60 $\mathrm{cm}$, a quadrangular stalk that is usually purple in color and smooth (Foster, 1996). The global peppermint essential oil production is about $8,000 \mathrm{t} /$ year. The main compounds of peppermint essential oil are menthol (29\%), menthon (20$30 \%$ ) and methyl acetate (1 to 3\%). Extraction of peppermint essential oil from the aerial parts of the plant at the beginning the flowering stage is usually by steam distillation method. About $30 \%$ to $70 \%$ of its essential oil is menthol and esters of menthol and the rest are more than 40 other compounds (Anonymous, 1990). Other compounds found in the peppermint essential oil include flavonoids (12\%), polymerized polyphenols (19\%), carotene, tocopherol betaine and choline (Murrray, 1995).
Currently, peppermint is used for the treatment of irritable bowel syndrome (IBS), inflammatory bowel disease (crohn and ulcerative colitis), gallbladder inflammation, biliary system defects and liver problems (Blumenthal, 1990; Fleming, 1998).

Peppermint is a long day plant (LDP) and it's planting in long day conditions leads to increase in its production and yield (Omid Beigi, 1995).

Singh and Chatterjee (1989) stated that nitrogen increase the vegetative growth in the plant and leaf area index, number of sub-branches and flowering branches; for example, within a crop of Mentha sativa, with the use of 150 $\mathrm{kg} / \mathrm{ha}$ nitrogen, the authors obtained the highest values of desired traits. Anvar et al. (2005) found that the application of $100 \mathrm{~kg} / \mathrm{ha}$ nitrogen fertilizer increased the number of branches, number of leave pigments and the dry matter per unit and yield of essential oils.

Ebhin Masto et al. (2006) studied the effect of micronutrients and planting density on essential oil content and essential oil yield of the peppermint plant and reported that the solution spraying of microelements produced the highest essential oil yield. 
246

Valad Abadi et al. (2008) reported on the effects of different levels of drought stress and nitrogen on the Calendula officinalis and showed the effect of nitrogen on the percentage essential oil yield were significant at $1 \%$ level. Akbarinia et al. (2012) evaluated effect of fertilizer on the percentage and yield of Trachyspermum ammi essential oil; they stated with increasing nitrogen and phosphorus, grain yield increased up to 90 and $60 \mathrm{~kg} / \mathrm{ha}$, respectively. Chemical fertilizers had no effect on essential oil percentage and $60 \mathrm{~kg} / \mathrm{ha}$ nitrogen, $40 \mathrm{~kg} / \mathrm{ha}$ phosphorus and 25 tons of manure per hectare and $60 \mathrm{~kg} / \mathrm{ha}$ nitrogen with 15 tons manure per hectare produced the highest grain and essential oil yield. Imam et al. (2014) reported that the use of nitrogen fertilizers increased the size, longevity and freshness of leaves and shoots in the plant. Also Balyan and Sobti (1990) reported that application rate of $80 \mathrm{~kg} / \mathrm{ha}$ nitrogen resulted in the accumulation and highest increase of dry matter in basil plant.

Indiscriminate use of chemical fertilizers, especially nitrogen, coupled with the lack of organic fertilizers, has resulted in recent years in significant reductions in the amount of organic matter in Iranian agricultural soils (Malekooti, 2018).

Green fertilizers are plants that are modified to improve the physical, chemical and biological properties of soils, (Table 1) and to supply essential nutrients for optimum plant growth in successive growing seasons (Cherr et al., 2016). The use of green fertilizers in addition to nitrogen fertilizers causes the nutrients to be readily available for crop production during the growing season and thus achieve more performance compared to the sole application of chemical fertilizers (Aktar et al., 1993; Paramanic et al., 2014).

\section{Materials and Methods}

The study was conducted from spring to fall of 20152016 in split factorial in a randomized complete block design (RCBD) with 3 replications. The nitrogen factor of urea source at four levels, $0,50,100,150 \mathrm{~kg} / \mathrm{ha}$ as the main factor and green manure, namely, alfalfa (Medicago sativa) and secale (Secale montanum) in two states (use and nonuse) as sub-factor were considered.

\section{Operation of cultivation}

Rooted branches with lengths of 8 to $10 \mathrm{~cm}$ from 2- to 3 -year-old plants were cut at 3 leaf stage from the main plants and cultivated in 12 plots (4 treatments with 3 replications) of $25 \mathrm{~m}^{2}$. The selected plants were similar in terms of size and height, and based on the main and subfactors, the treatments were divided into 4 rows. The first group consisted of four rows for application of nitrogen fertilizer $(0,50,100,150 \mathrm{~kg} / \mathrm{ha})$, one third of the assigned nitrogen fertilizer was applied at planting and the rest was distributed at the 6 to 8 leaf stages in the field. In the second and third groups, the first stage involved the cultivation of $M$. sativa and $S$. montanum in September 2015, asynchronous as green manure and ploughing them into the soil in the fall of 2015. In the fourth group, the cultivation of $M$. sativa and $S$. montanum was carried out simultaneously. The nitrogen treatments herein were applied as done previously to investigate the interaction of the treatments. Planting was done in early May 2016 and due to the high sensitivity of Mentha piperita to drought stress in the region, irrigation was carried out every 4 days. Weed control was done manually owing to the experimental design adopted and the medicinal properties of the peppermint plant.

From the beginning of the vegetative stage to the end, weeding was carried out continuously. There was no incidence of pest invasion; hence, chemical pest control was not carried out. This was achieved as a result of the scent emitted by the plant.

After harvest, the yield of fresh weight was determined immediately and to determine the yield of dry weight, samples were dried at room temperature $\left(25^{\circ} \mathrm{C}\right)$ and in shade for 10 days and then weighed. In order to determine the percentage and yield of $M$. piperita essential oil obtained from the different treatments, the samples were dried and weighed at room temperature and in shade, than subjected to laboratory analyses, wherein essential oil was obtained by the water distillation method. The Clevenger device was used to calculate the essential oil percentage dehydration by dry sodium sulfate $\left(\mathrm{Na}_{2} \mathrm{SO}_{4}\right)$. The essential oil yield was obtained from the multiplication of the essential oil percentage in the biological function divided of 100 . Data was analyzed by MSTAT-C software, and mean comparison was carried with the Duncan's method at 5\% level of significance.

Table 1. Physical and chemical properties of the experiment soil

\begin{tabular}{cc}
\hline Soil property & Value \\
\hline $\mathrm{Cu}(\mathrm{ppm})$ & 1.60 \\
$\mathrm{Mg}(\mathrm{ppm})$ & 24.80 \\
$\mathrm{Mn}(\mathrm{ppm})$ & 9.88 \\
$\mathrm{P}(\mathrm{ppm})$ & 12.50 \\
$\mathrm{~K}(\mathrm{ppm})$ & 255.00 \\
$\mathrm{~N}(\mathrm{ppm})$ & 0.08 \\
$\mathrm{CaCO}_{3}(\mathrm{ppm})$ & 6.00 \\
$\mathrm{Texture}$ & Loam \\
Sand $(\%)$ & 38.00 \\
Silt $(\%)$ & 35.00 \\
Clay $(\%)$ & 27.00 \\
\hline
\end{tabular}




\section{Results}

\section{Essential oil percentage}

The results presented in Table 2 show that the individual effect of nitrogen on essential oil percentage of Mentha piperita was significant $(\mathrm{p}<5 \%)$. From Table 3, it can be noted that the highest and lowest essential oil (\%) were obtained from the application of $150 \mathrm{~kg} / \mathrm{ha}$ nitrogen $($ mean $=0.35 \%)$ and the control treatment (mean $=$ $0.15 \%$ ), respectively. Omid Beigi (1995) and Anvar et al. (2005) reported that the application of $100 \mathrm{~kg}$ of nitrogen would increase the yield of the branches, the number of leaves, pigment of leaves and increase of dry matter yield per unit area and yield of essential oil. Also, Bist et al. (2000) found that with addition of nitrogen fertilizer to soil, percentage and some components of Anethum graveolens dhi essential oil increased.

The individual effect of incorporating Medicago sativa as green manure on Mentha piperita essential oil percentage was significant $(\mathrm{p}<5 \%)$ (Table 2$)$. The highest percentage of essential oil was obtained from the incorporation of $M$. sativa as $0.43 \%$, and the lowest obtained from the control treatment (non-use of this green manure) as $0.20 \%$ (Table 3 ). From Table 2 , the individual effect of incorporating $S$. montanum as green manure on the essential oil percentage of Mentha piperita was significant at level $1 \%(\mathrm{p}<1 \%)$. The highest and lowest percentages of essential oil were obtained from the incorporation of $S$. montanum as $0.44 \%$, and the control treatment (non-use of this green manure) as $0.25 \%$, respectively (Table 3 ).

These observations could be attributed to the soil's ability to retain more moisture as a result of improved soil structure upon the incorporation of the green manure treatments. This ultimately resulted in the increased biological yield of the peppermint plant and its essential oil yield. On the other hand, the increase in essential oil from the application of different fertilizer treatments could be due to the readily availability of nutrients such as nitrogen and phosphorus for the formation of ATP and NADPH, which serve in the pathway to the formation of terpenoids and isoprenoids in the essential oils (Loomis and Corteau, 1972).

The interactions of nitrogen fertilizer with incorporated $M$. sativa and $S$. montanum on the percentage of essential oil at $1 \%$ and $5 \%$ levels of significance, respectively, are presented in Table 2 . The highest percentage of essential oil was obtained from $150 \mathrm{~kg} / \mathrm{ha}$ nitrogen in combination with incorporated $M$. sativa (0.62\%), and the lowest percentage, obtained from the control treatment as $0.13 \%$ (Table 4 ). Similarly, the highest percentage of essential oil was obtained from the combined effects of $150 \mathrm{~kg} / \mathrm{ha}$ nitrogen and incorporated $S$. montanum (mean $=0.41 \%$ ), and the lowest percentage from the control treatment with a mean value of $0.14 \%$ (Table 4 ). In a similar study, Valad Abadi et al. (2008) investigated the effects of different levels of nitrogen on Calendula officinalis and concluded that nitrogen increased the percentage and yield of its seed oil.

The interaction of Medicago sativa and Secale montanum incorporated as green manures on the percentage of essential oil at 5\% level of significance is presented in Table 2. The highest percentage with mean of $0.48 \%$ essential oil was obtained from the use of both $M$. sativa and $S$. montanum as green manures, and the lowest percentage from the control with a mean of $0.16 \%$ (Table 4).

The triple interaction of nitrogen, and Medicago sativa and Secale montanum green manures on the percentage of essential oil was significant $(\mathrm{p}<1 \%)$ (Table 2$)$. The highest percentage of essential oil of $0.73 \%$ was obtained from the treatment with $150 \mathrm{~kg} / \mathrm{ha}$ nitrogen and the two green manures, while the lowest percentage with mean of $0.73 \%$ and the lowest from the control with a mean value of $0.12 \%$ (Table 5). Similar to the study by Akbarinia et al. (2012), fertilizer application resulted in the increase in essential oil content and essential oil yield in Trachyspermum ammi. They also stated that application of nitrogen and phosphorus up to 60 and $90 \mathrm{~kg} /$ ha respectively resulted in increased grain yield size, longevity of leaves and branching, and also increased the freshness of leaves on plants.

Table 2. Analysis of variance of Nitrogen, Medicago sativa and Secale montanum green manure application on the percentage and yield of essential oil of Menthapiperita

\begin{tabular}{|c|c|c|c|}
\hline \multirow{2}{*}{ SOV } & \multirow{2}{*}{$\mathrm{df}$} & \multicolumn{2}{|c|}{ MS } \\
\hline & & Essential oil percentage & Essential oil yield (kg/ha) \\
\hline Replication & 2 & $1.280^{\mathrm{ns}}$ & $6,325,648.333^{\mathrm{ns}}$ \\
\hline $\mathrm{N}$ & 3 & $182.025^{\circ}$ & $3,325,416.226$ \\
\hline Error & 6 & 20.335 & $358,469.875$ \\
\hline Me.sa & 1 & $2,225.036^{*}$ & $72,136,548.215^{\prime \prime}$ \\
\hline Se.mo*Me.sa & 3 & $48.387^{\star}$ & $2,569,823.7012^{*}$ \\
\hline Se.mo & 1 & $523.081^{*}$ & $13,269,587.658^{* *}$ \\
\hline $\mathrm{N}^{*}$ Se.mo & 3 & 11.685 & $2,569,875.325^{\prime \prime}$ \\
\hline Me.sa*Se.mo & 1 & $52.431^{*}$ & $22,564.548^{*}$ \\
\hline $\mathrm{N}^{*}$ Me.sa ${ }^{*}$ Se.mo & 3 & $83.152^{\circ}$ & $203,269.559^{\circ}$ \\
\hline Error & 24 & 25.325 & $1,352,648.562$ \\
\hline CV $(\%)$ & - & 13.23 & 8.2 \\
\hline
\end{tabular}


Table 3. Comparison of the average effect of Nitrogen, Medicago sativa and Secale montanum green manures on the percentage and yield of essential oil of Menthapiperita

\begin{tabular}{ccc}
\hline Treatment & Essential oil percentage & Essential oil yield $(\mathrm{kg} / \mathrm{ha})$ \\
\hline Nitrogen $(\mathrm{kg} / \mathrm{ha})$ & & $0.15 \mathrm{~d}$ \\
0 & $0.20 \mathrm{c}$ & $20.23 \mathrm{~b}$ \\
50 & $0.22 \mathrm{~b}$ & $27.53 \mathrm{c}$ \\
100 & $0.35 \mathrm{a}$ & $30.45 \mathrm{a}$ \\
150 & & $45.60 \mathrm{a}$ \\
Medicago sativa green manure & $0.20 \mathrm{~b}$ & $23.66 \mathrm{~b}$ \\
non-use & $0.43 \mathrm{a}$ & $55.80 \mathrm{a}$ \\
use & $0.25 \mathrm{~b}$ & $21.13 \mathrm{~b}$ \\
Secale montanum green manure & $0.44 \mathrm{a}$ & $49.50 \mathrm{a}$ \\
\hline non-use &
\end{tabular}

Table 4. Comparison of the average double interaction of Nitrogen, Medicago sativa and Secale montanum on the percentage and yield of essential oil of Menthapiperita

\begin{tabular}{|c|c|c|c|}
\hline Treatment & & Essential oil percentage & Essential oil yield $(\mathrm{kg} / \mathrm{ha})$ \\
\hline Nitrogen $(\mathrm{kg} / \mathrm{ha})$ & Medicago sativa green manure & & \\
\hline \multirow{2}{*}{0} & non-use & $0.13 \mathrm{e}$ & $11.26 \mathrm{ef}$ \\
\hline & use & $0.25 \mathrm{~d}$ & $33.70 \mathrm{c}$ \\
\hline \multirow{2}{*}{50} & non-use & $0.11 \mathrm{e}$ & $14.01 \mathrm{ef}$ \\
\hline & use & $0.30 \mathrm{c}$ & $42.58 \mathrm{c}$ \\
\hline \multirow{2}{*}{100} & non-use & $0.16 \mathrm{e}$ & $20.44 f$ \\
\hline & use & $0.39 \mathrm{~b}$ & $53.38 b$ \\
\hline \multirow{2}{*}{150} & non-use & $0.23 \mathrm{e}$ & $22.03 \mathrm{e}$ \\
\hline & use & $0.62 \mathrm{a}$ & $80.30 \mathrm{a}$ \\
\hline Nitrogen $(\mathrm{kg} / \mathrm{ha})$ & Secale montanum green manure & & \\
\hline \multirow{2}{*}{0} & non-use & $0.14 \mathrm{a}$ & $15.06 \mathrm{~d}$ \\
\hline & use & $0.22 b$ & $27.26 \mathrm{~d}$ \\
\hline \multirow{2}{*}{50} & non-use & $0.15 c$ & $21.38 \mathrm{c}$ \\
\hline & use & $0.28 \mathrm{a}$ & $38.05 \mathrm{ab}$ \\
\hline \multirow{2}{*}{100} & non-use & $0.20 \mathrm{bc}$ & $25.46 c$ \\
\hline & use & $0.34 \mathrm{a}$ & $44.33 b$ \\
\hline \multirow{2}{*}{150} & non-use & $0.27 \mathrm{bc}$ & $34.62 \mathrm{c}$ \\
\hline & use & $0.41 \mathrm{a}$ & $55.90 \mathrm{a}$ \\
\hline Medicago sativa green & Medicago sativa green manure & & \\
\hline \multirow{2}{*}{ non-use } & non-use & $0.16 \mathrm{~d}$ & $15.39 \mathrm{~d}$ \\
\hline & use & $0.16 \mathrm{c}$ & $21.38 \mathrm{c}$ \\
\hline \multirow{2}{*}{ use } & non-use & $0.21 b$ & $28.85 b$ \\
\hline & use & $0.48 \mathrm{a}$ & $48.13 \mathrm{a}$ \\
\hline
\end{tabular}

Table 5. Comparison of the average triple interaction of Nitrogen, Medicago sativa and Secale montanum green manures on the percentage and yield of essential oil of Mentha piperita

\begin{tabular}{|c|c|c|c|c|}
\hline \multicolumn{3}{|c|}{ Average } & \multicolumn{2}{|c|}{ Treatment } \\
\hline Essential oil yield $(\mathrm{kg} / \mathrm{ha})$ & Essential oil percentage & Secale montanum green manure & Medicago sativa green manure & Nitrogen $(\mathrm{kg} / \mathrm{ha})$ \\
\hline $13.20 \mathrm{i}$ & $0.12 \mathrm{i}$ & non-use & \multirow{2}{*}{ non-use } & \multirow{4}{*}{0} \\
\hline $23.25 \mathrm{gh}$ & $0.19 \mathrm{gh}$ & use & & \\
\hline $31.06 \mathrm{ef}$ & $0.22 \mathrm{ef}$ & non-use & \multirow{2}{*}{ use } & \\
\hline $44.77 \mathrm{~cd}$ & $0.31 \mathrm{c}$ & use & & \\
\hline $16.38 \mathrm{i}$ & $0.15 \mathrm{i}$ & non-use & \multirow{2}{*}{ non-use } & \multirow{4}{*}{50} \\
\hline $27.65 \mathrm{~h}$ & $0.23 \mathrm{~h}$ & use & & \\
\hline $2.66 \mathrm{fg}$ & $0.29 \mathrm{fg}$ & non-use & \multirow{2}{*}{ use } & \\
\hline $52.62 \mathrm{de}$ & $0.38 \mathrm{de}$ & use & & \\
\hline $20.49 \mathrm{i}$ & $0.17 \mathrm{i}$ & non-use & \multirow{2}{*}{ non-use } & \multirow{4}{*}{100} \\
\hline $34.66 \mathrm{~h}$ & $0.25 \mathrm{gh}$ & use & & \\
\hline 48.77cde & $0.34 \mathrm{~cd}$ & non-use & \multirow{2}{*}{ use } & \\
\hline $65.09 \mathrm{~b}$ & $0.46 b$ & use & & \\
\hline $24.52 \mathrm{i}$ & $0.21 \mathrm{i}$ & non-use & \multirow{2}{*}{ non-use } & \multirow{4}{*}{150} \\
\hline $37.55 \mathrm{gh}$ & $0.27 \mathrm{gh}$ & use & & \\
\hline $57.36 \mathrm{bc}$ & $0.36 \mathrm{bc}$ & non-use & \multirow{2}{*}{ use } & \\
\hline $91.65 \mathrm{a}$ & $0.73 \mathrm{a}$ & use & & \\
\hline
\end{tabular}


Essential oil yield

The individual effect of nitrogen on essential oil yield of Mentha piperita was significant ( $<<5 \%)$ (Table 2). The highest yield was obtained from the application of 150 $\mathrm{kg} / \mathrm{ha}$ nitrogen $(45.60 \mathrm{~kg} / \mathrm{ha})$ and the lowest from the control (20.23 kg/ha) (Table 3 ). According to these results, the increase in nitrogen application from zero to $150 \mathrm{~kg} / \mathrm{ha}$ resulted in increased essential oil percentage and essential oil yield/unit area (Table 4). These results are a clear indication of the role of nitrogen in increasing the vegetative growth in plants, hence, increases in total dry matter yield per unit area. A close analysis of the results revealed that the triple interaction of nitrogen, Medicago sativa and Secale montanum green manures had the most significant effect on the percentage and yield of essential oil, which implies that the combined effect of these treatments have an enormous effect compared to their individual and cross-linking effects.

The individual effects of Medicago sativa and Secale montanum green manures on essential oil yield of Mentha piperita were significant $\mathrm{p}<1 \%$ (Table 2). From the obtained results, the highest yields of essential oil were obtained from the incorporation of $M$. sativa and $S$. montanum $(55.80 \mathrm{~kg} / \mathrm{ha}$ and $49.50 \mathrm{~kg} / \mathrm{ha}$, respectively) and the lowest from the control treatment (non-use of this green manure) with mean values of $23.66 \mathrm{~kg} / \mathrm{ha}$ and 21.13 $\mathrm{kg} / \mathrm{ha}$, respectivelywere obtained (Table 3 ).

The interactions of nitrogen fertilizer and the green manures from Medicago sativa and Secale montanum on the yield of essential oil were significant at $1 \%$ and $5 \%$, respectively (Table 2). From the results, it is obvious that the green manures from Medicago sativa and Secale montanum complemented the role of the nitrogen fertilizer to effectively meet the plant requirement. The highest yield of essential oil in the $150 \mathrm{~kg} / \mathrm{ha}$ nitrogen and use of green manure of Medicago sativa and Secale montanum were $80.30 \mathrm{~kg} / \mathrm{ha}$ and $55.90 \mathrm{~kg} / \mathrm{ha}$, respectively. The control treatments in relation to these treatments, however, produced and the lowest yields to the tune of $11.26 \mathrm{~kg} / \mathrm{ha}$ and $15.06 \mathrm{~kg} / \mathrm{ha}$, respectively (Table 4).

The combined effect of Medicago sativa and Secale montanum green manures on the yield of essential oil was significant at $5 \%$ (Table 2). The highest yield of essential oil obtained in this regard was $48.13 \mathrm{~kg} / \mathrm{ha}$ and the lowest yield, from the control being $15.39 \mathrm{~kg} / \mathrm{ha}$ (Table 4). The triple interaction of nitrogen and two green manures on the yield of essential oil was also significant at $1 \%$ (Table 2).

\section{Discussion}

Under the present treatment, the highest yield of essential oil with a mean of $91.65 \mathrm{~kg} / \mathrm{ha}$ was obtained from the application of $150 \mathrm{~kg} / \mathrm{ha}$ nitrogen in combination with the green manures from Medicago sativa and Secale montanum. The lowest yield of $13.20 \mathrm{~kg} / \mathrm{ha}$, however, was obtained from the control treatment (Table 5). Similarly, Banchio et al. (2009) reported that the application of biological fertilizers to basil plants was very effective in increasing the biomass and yield of essential oils. Thus, the positive effects of bio fertilizers such as incorporation of green manures on improving the nutritional conditions in plants have been proven in the hereby study.

\section{Conclusions}

Generally, the use of crop techniques and environmental factors in the cultivation of crops to increase the amount of active ingredients is a very interesting and important subject matter, for example the use of legumes as green fertilizers, thus nitrogen will be released gradually over a long period of time to enhance nitrogen absorption by plants during successive growing periods. According to the results obtained in the current study, the application of different types of bio fertilizers, both singularly and in combination resulted in the increase in the yield of essential oil of peppermint. Thus, the incorporation of Medicago sativa and Secale montanum as green manures, especially by smallholder farmers, will serve as a good alternative to application of chemical fertilizers.

\section{Acknowledgements}

The authors are thankful to University of Kashan for supporting this research.

\section{References}

Akbarinia A, Rezaei MB, Tahmasebi Z, Sefidkon F, Sharifi Ashoorabadi A, Qhalavand A (2012). Investigation of different systems of nutrition on yield and amount of essential oil of Carum copticum Heirn seed. Iranian Journal of Medicinal and Aromatic Plants Research 18:56-68.

Aktar MS, Hasan MK, Adhikery R, Chowdhary MK (1993). Integrated management of Sesbania rostrata and urea nitrogen in rice-rice cropping system. The Annals of Bangladesh Agriculture 3(2):109-114.

Anonymous (1990). Peppermint. In: Dombek C (Ed). Lawerence Review of Natural Products. St. Louis: Facts and Comparison.

Balyan S, Sobti N (1990). Effect of nitrogen, phosphor and potassium on dry matter accumulation and nutrient uptake in basil (Ocimum gratissimum L.).Indian Perfumer 34(3):225-231.

Banchio E, Xie X, Zhang H, Pare PW (2009). Soil bacteria elevate essential oil accumulation and emissions in sweet basil. Journal of Agricultural andFood Chemistry 57(2):653-657.

Bist LD, Kewaland CS, Pandey S (2000). Effect of planting geometry and N levels on growth yield and quality of Europen oil (Anenthum grareloens Linn.). Indian Journal of Horticulture 57(4):351-355.

Blumenthal M(1998). Therapeutic guide to herbal medicines.

Cherr CM, ScholbergJMS, McSorley R (2016). Green manure approaches to crop production Florida Agric. Exp. Stn. Journal Series no. R-10702. Agronomy Journal 98(2):302-319.

Ebhin Masto R, Chhonkar PK, Singh D, Patra AK (2006). Changes in soil biological and biochemical characteristics in a long-term field trial on a sub-tropical inceptisol. Soil Biology and Biochemistry38(7):1577-1582.

Fleming T (1998). PDR for herbal medicines. Montvale, Medical Economics Company, Inc, Montvale pp 98-106.

Foster S (1996). Peppermint: Menthapiperita. American Botanical Council - Botanical Series 306:3-8.

Imam Y, Niknejad M (2014). Introduction to physiology of crop yields. Shiraz University Press.

Loomis WD, Corteau R (1972). Essential oil biosynthesis. Recent Advances in Phytochemistry 6:147-185. 
250

Malekooti M (2018). Sustainable agriculture and increasing yield by optimizing fertilizer use in Iran. First Edition. Agri Edu Press, Karaj.

Murrray MT (1995). The healing power of herbs: The enlightened person's guide to the wonders of medicinal plants. Rocklin, CA, Prima Pub: xiv, pp410.

Omid Beigi R (1995). Approaches to the production and processing of medicinal plants. Astan Quds Razavi Press.

PeirceA(1999). The American Pharmaceutical association practical guide to natural medicines. New York: William Morrow and Company, Inc. 2th Edition.
Paramanic MYA, Sarkar MAR, Islam MA, Samad MA (2014). Effect of green manures and different levels of nitrogen on the yield and yield components of transplant Aman rice. Journal of Agronomy 3(2):122125.

Singh VP, Chatterjee BN (1989). Response of mint species to nitrogen fertilization. The Journal of Agricultural Science 113(2):267-271.

Valid Abadi AS, Rahmani R, Daneshian N, Bigdeli M (2008). Effect of different levels of drought stress and nitrogen on oil yield in medicinal Calendula officinalis. Iranian Journal of Medicinal and Aromatic Plant Research 1(39):101-115. 